\title{
Humphrey and the Old Revolution: Human Rights in the Age of Mistrust ${ }^{1}$
}

\section{by A.J. Hobbins}

John P. Humphrey wrote the first draft of the Universal Declaration of Human Rights and was one of the key United Nations Secretariat figures in the post-war human rights programme. Humphrey was a socialist and the Universal Declaration contained social and economic rights from its very beginnings. The inclusion of these rights made the Universal Declaration an object of attack from the American right as an instrument to introduce state socialism. Humphrey by and large escaped any public attack as an individual, but a few of his friends and a number of his acquaintances were alleged to be Soviet agents. This article investigates Humphrey's associations from the 1930s to the 1950s, based in part on his diaries and other unpublished materials, in order to analyze how those associations might have affected the U.N. Human Rights programme.

John P. Humphrey a rédigé la première version de la Déclaration universelle des droits de l'homme et a joué un rôle capital dans le programme des droits de l'homme du Secrétariat des Nations Unies. Humphrey était socialiste et à ce titre, il a veillé à ce que la Déclaration universelle tienne toujours compte des droits économiques et sociaux. $L$ 'inclusion de ces droits a conduit la droite américaine à ne voir dans la Déclaration universelle qu'un instrument du socialisme d'État. Humphrey a personnellement échappé à la vindicte publique mais quelques-uns de ses amis et plusieurs de ses connaissances ont été accusés d'être des agents soviétiques. S'appuyant sur ses journaux intimes et d'autres documents non publiés, cet article s'intéresse aux sympathies de Humphrey entre les années 1930 et 1950 pour détérminer comment elles ont modulé le programme des droits de l'homme des Nations Unies.

$\mathbf{W}$ hen the United Nations decided there would be an international bill of human rights, two immediate problems faced those charged with responsibility for its production. First, international law up to this juncture had essentially been the law of nations, recognizing states but having no precedents or provisions concerning individuals. Therefore any declaration or covenant recognizing individuals meant a radical departure from the past, such departures being inherently controversial. Second, the United Nations and, indeed, the world was dominated by two antithetical ideologies. The capitalist West-in particular powerful, conservative elements within the U.S.A.-believed most firmly in the sanctity of civil and political rights, while rejecting social, economic and cultural rights as an insidious form of socialism, or worse. Conversely the Soviet bloc stressed, at least publicly, the importance of social and economic rights but were strenuously opposed to those civil and political rights which might favour the individual over the collective.
In January 1947, the executive of the Human Rights Commission-Eleanor Roosevelt (Chairman), P.C. Chang (Vice-Chairman) and Charles Malik (Rapporteur) - asked John Humphrey (Director of the U.N. Division of Human Rights) to prepare a first draft for an international bill. He realized the extreme difficulty of satisfying all factions. He determined that such a bill must include provisions for both civil and political, as well as social and economic rights. This duality was retained from the first Humphrey draft to the final text of the Universal Declaration of Human Rights. The basic strategy through hundreds of meetings involving thousands of individuals was to generate a text that was both meaningful and acceptable to nations of differing philosophies. When the Universal Declaration was ultimately presented to the General Assembly on December 10,1948, no member state voted against its adoption, although there were a number of abstentions. South Africa, on the threshold of implementing the policy of Apartheid, was not interested in giving certain rights to its Black subjects. Saudi Arabia could not accept the concept of the right to change religion, apostasy from Islam being 


\section{Humphrey and the Old Revolution}

proscribed in the Koran. ${ }^{1}$ The six nations of the Soviet bloc also abstained. Canada had abstained two days earlier during the vote in the Third Committee but, possibly not liking the company it was in, voted positively in the General Assembly.

Humphrey's duties included the need to explain the Secretariat's role in human rights issues to the public in a low profile and apolitical fashion. It was important that he should appear relatively neutral in terms of ideology since obvious partisanship would reflect negatively on the programmes of his division, including the Universal Declaration. In July 1947, he addressed the American Academy of Political and Social Science at Ann Arbor. In his speech to this gathering of scholars he described the U.N.'s effort to create a body of international law that pertained to the individual as "revolutionary in character". When the speech was published in $1948^{2}$ this innocuous phrase was seized upon by the North American right as a reason to attack the Declaration. In his diary for September 21, 1948, Humphrey noted:

My attention has been drawn to a speech by the President of the American Bar Association, Frank E. Holman, as reported in the N.Y. Times of Sept. 18. He says that the U.N. human rights programme is an attempt to establish State socialism "if not communism". Dolivet ${ }^{3}$ tells me that in another N.Y. paper he is reported as having mentioned me personally as having admitted the "revolutionary" character of the programme. Of course it will be revolutionary if we succeed; but there is nothing particularly revolutionary in what we have done up until now. ${ }^{4}$

Frank E. Holman (1886-1967) was an influential Seattle lawyer who, in addition to being President of the American Bar Association, had been on the American Bar Committee for Peace and Law through the United Nations (1946-1947). He was joined in his attacks by John T. Hackett (1884-1956), a Montreal lawyer and politician, who was President of the Canadian Bar Association from 1947-1948. Hackett was a Progressive Conservative M.P. (1945-1949) and Parliamentary Advisor to the Canadian Delegation to the General Assembly. Indeed Holman and Hackett met on several occasions in 1948 to discuss joint opposition to the Declaration, ${ }^{5}$ and there is some evidence that Hackett may have been responsible in part for the Canadian abstention in the Third Committee. Humphrey noted in his diary:

Miss Carlisle ${ }^{6}$ is an information officer in the Canadian Department of External Affairs and was with the Canadian Delegation at Paris. She tells me it was John T. Hackett, president of the Canadian Bar Association, who led the campaign against the Declaration in Canada. I would like to know whether and to what extent the Canadian Bar Association was influenced by the American Bar Association which has, of course, fought the project for months. ${ }^{7}$

And a few days later:
Jack Angevin has sent me an editorial entitled "Human Rights on Pink Paper" which appeared in the Montreal Gazette of January $17^{\text {th }}$. It quotes my now famous statement at Ann Arbor that what the United nations is trying to do in the field of human rights is revolutionary in character. It also quotes Mr. Holman, the President of the American Bar Association, who it seems had a lot to do with the Canadian abstention on the vote in the committee stage in Paris. I read in this connection a statement written by $\mathrm{Mr}$. Holman in a recent issue of the organ published by the American Bar Association where he refers to a trip to Montreal last August to attend a meeting of the Canadian Bar Association and his talks with Mr. John T. Hackett. ${ }^{8}$

The Montreal Gazette editorial termed the Declaration "Human Rights on Pink Paper" because it failed to enshrine the right to own private property. What the editorial overlooked was that a declaration attempting to be universal could scarcely enshrine such a right when the Soviet states, and a number of other societies, had no concept of private property. Thus the Declaration had powerful foes whose enmity continued long after its adoption. Joseph McCarthy considered the U.N. as little more than a nest of spies and Soviet 


\section{Humphrey and the Old Revolution}

propagandists, and even as late as 1962 Barry Goldwater was quoting Humphrey's "admission" that the human rights programme was revolutionary to prove a point about the socialist nature of the Declaration. ${ }^{9}$

It was evident that there existed a great fear of the left in the U.S. and Canada at this time. The least fact, such as the use of the word "revolutionary" to describe a new approach, was used out of all proportion to its significance. Certainly in hindsight Humphrey regretted using the word in his address. This was, however, a relatively minor issue and most reasonable people would understand the term in the context it was made. It would be far more problematic if Humphrey could have been personally attacked for strong socialist sympathies, for membership in left-wing organizations, or for the beliefs of those people with whom he associated. Guilt by association was a favourite tactic of the American right when launching its attacks on individuals during this period. In this regard Humphrey was extremely fortunate that certain aspects of his past and his acquaintances never came to light.

\section{THE CANADIAN LEFT}

As a young man Humphrey was a socialist. He was a member of the League for Social Reconstruction ${ }^{10}$ with other left-wing intellectuals such as Frank Scott, ${ }^{11}$ David Lewis, ${ }^{12}$ Frank Underhill, ${ }^{13}$ Eugene Forsey ${ }^{14}$ and King Gordon. ${ }^{15}$ While the League was initially a general socialist discussion group, it began to focus on Canadian rather than international issues. This direction was not to Humphrey's taste. As be noted in his diary:

My experience, even in Canada, has been that socialists are so preoccupied with domestic questions that they had no energy and time left for what is happening in the international community. This is true even of as enlightened and intelligent [a] person as Frank Scott. ${ }^{16}$

When Scott and Underhill determined the time was right for concrete political action, the League evolved into the Cooperative Commonwealth Federation, Canada's first socialist political party. Candidates were fielded in the 1935 federal election, including Gordon who was defeated in Victoria, B.C. Humphrey was no longer active when the transition to the C.C.F. took place. However, he remained sympathetic to the League's ideals and friendly with the members, and he continued to advocate the need for social security. His association with Canadian socialism was not generally known because he had dropped out before the CCF raised the socialist profile. By the time he went to the U.N., his political views had evolved, although he remained basically a socialist. On September 8, 1948, he confided to his diary:

Surely a world that can achieve the atomic
bomb but fail in the creation of the United
Nations is morally bankrupt. And this moral
bankruptcy is the reason for our failure to
organize peace. I once thought that
socialism could fill this moral gap; but
now, although I still remain a socialist, I
know better. For Socialism is a technique
and nothing more. What we need is
something like the Christian morality
without the tommyrot. ${ }^{17}$

Even in Canada Humphrey's connection to the socialist movement appears to have remained obscure. In 1950, the Canadian Senate began hearings into the possibility of drafting a Canadian Bill of Rights. Humphrey was invited by Senator Roebuck ${ }^{18}$ to testify. He wrote back to say that he would be in South America at the relevant time but would send one of his staff, King Gordon, instead. Irving Himel, the Secretary of the Toronto Civil Liberties Association, begged him to reconsider.

Mr. Himel wrote to me objecting to my designation of King Gordon as the man to represent me at the Canadian Senate Committee meeting. Says that King Gordon is too closely connected with the C.C.F. that F.R. Scott will appear, etc. I rejected the objection and King will go. ${ }^{19}$

Ironically, although Humphrey had been Gordon's fellow traveller, he was politically acceptable to the centre when Gordon was not.

It is quite usual, even expected, for young people to have left-wing leanings. Even had his socialist sympathies been well known, Humphrey, like so many 
others, could probably have lived down his leftist past, cloaking it in the shadow of middle-aged respectability. However, he would have had considerably greater difficulty living down the suspicion that some of his acquaintanceships would have engendered.

\section{THE CANADIAN SPY RING}

Before joining the Faculty of Law, Humphrey practised law at Wainwright, Elder and McDougall (1930-1936). He and his wife, Jeanne, lived in an apartment building on Cote des Neiges and became friendly with another young couple, Eric and Josepha Adams. ${ }^{20}$ Eric Adams (1907- ) had graduated from McGill in 1929 with a degree in Engineering, and then took an M.B.A. (1931) at Harvard. He returned to Montreal to work for the advertising agency, CockfieldBrown, for four years. Although he had met Humphrey as an undergraduate, they became friends only after Adams' return to Montreal. During visits to one another's apartments, they used to argue about politics, Adams being far to the left of Humphrey's socialism. Humphrey's theory regarding Adams' political orientation was that as an engineer Adams expected mathematically precise answers to problems, and so, when he switched his field to economics, he naturally gravitated towards Marxism-the one philosophy that claimed to offer precise answers. The discussions between Humphrey and Adams were usually quite heated, so much so that Jeanne Humphrey became disturbed by them and suggested the couples see less of one another. The visits became less frequent and then ceased altogether shortly before the Adams moved away. Adams visited Russia (1934) and then moved to the U.S. until 1939. During the war he returned to Ottawa and worked for the Wartime Requirements Board (1940), the Foreign Exchange Control Board and Bank of Canada (1941-1944), and, moving to Montreal, for the Industrial Development Bank (1945).

Soviet cypher clerk Igor Gouzenko's dramatic defection from the Soviet embassy in Ottawa was to change Adams' life. On September 5, 1945, Gouzenko took a number of papers relating to the existence of a Soviet spy ring in Canada from the embassy safe. He went to the Ottawa Journal where he was told to come back in the morning or go to the R.C.M.P. The city editor was too busy to see him, thereby missing the scoop of a lifetime. He then tried the Minister of Justice, Louis St. Laurent, but was also told to come back the following day. The next day he again visited the Minister of Justice and was once more rebuffed, although he told the secretary to whom he spoke that he was left with no alternative but suicide. Returning home with his wife, he noticed that two men were watching the apartment and assumed they were Soviet agents. In fact these were Canadian agents sent by Prime Minister Mackenzie King. King had been informed about Gouzenko that morning by Norman Robertson, the Under-Secretary of State for External Affairs, and wrote in his diary:

We learned later that the Russian man had left saying he was going to his own flat; that there was nothing but suicide ahead of him. Again, Robertson thought of getting the police to seize the papers, I suggested that a Secret Service man in plain clothes watch the premises. If suicide took place let the city police take charge and this man to follow in and secure what there was in the way of documents, but on no account for us to take the initiative. ${ }^{21}$

King was anxious to avoid any diplomatic confrontation with the Soviet Union.

Gouzenko hid in a neighbour's apartment, while he tried to decide his next step. At this point four members of the Soviet staff broke into Gouzenko's apartment. The Ottawa city police were called by the neighbour and when they tried to make an arrest, all four Soviets claimed diplomatic immunity. When the police heard the story, they contacted the R.C.M.P. who, on instructions from Robertson, placed Gouzenko and the papers under their protection. Gouzenko's defection was safely completed despite the callousness and indifference he had encountered.

The Gouzenko papers showed the existence of an extensive spy ring in Canada. Justices Taschereau and Kellock of the Supreme Court were appointed to a Royal Commission to inquire into the matter. In his subsequent testimony before the Royal Commission on February 13, 1946, Gouzenko identified the Soviet agent with the codename "Ernst" as "Eric Adams". Unlike some of his other identifications, he was unable 
to provide more information than the name. The identification was based on having seen a file compiled by Lieutenant-Technical Gouseev, but the file was not amongst the papers Gouzenko took. The following day one of the Counsel for the Commission, Gérald Fauteux, ordered Adams' arrest. Adams was in Prince Albert, Saskatchewan, when the officers came to his house in Montreal. After they had left, Josepha Adams sent him a telegram that read "Helen's baby dying. Will send you further word. Sally".22 When Adams was arrested in Saskatchewan, she contacted Humphrey for the name of a lawyer and he provided a referral to a local criminal practitioner.

Adams was held in detention by the Commission under the War Measures Act for over a month without the benefit of habeas corpus or legal advice. Another witness, Kathleen Willsher, assistant registrar in the British High Commission who was subsequently found guilty of espionage, identified Adams as the leader of a communist cell, or study group, in Ottawa to whom she had passed information. Adams first appeared before the Commission on March 15th, 1946, and showed himself to be a shrewd individual, to the evident exasperation of the Commissioners and their Counsels. He refused to take the oath until it had been modified to his satisfaction and then refused to testify without access to counsel. The Commissioners explained that he was merely a witness and that they would decide when it was appropriate for him to be represented by a lawyer. Adams remained adamant. When he finally received counsel he proved a difficult and evasive witness, with poor powers of recall. Had the issue been less serious, some of the exchanges between Adams and the Commission's Counsels (who usually came off second best) could be viewed as quite amusing. Adams refused to convict himself by his own testimony, and the Commissioners became frustrated with his evasiveness. In their report they used harsh words for Adams and concluded: "We are satisfied on the evidence that Adams was an important unit in Zabotin's organization". ${ }^{23}$

On the Commission's recommendation, Adams was subsequently tried in Federal Court on a charge of conspiracy to communicate information. The court was less impressed than the Commission with the evidence, which consisted essentially of some cryptic papers stolen from an embassy, a vague identification, and the fact that he owned some books about Communism. Nor apparently was the prosecution able to use all the witnesses that the Commission had heard in camera. While there was plenty of evidence about Adams' Marxist leanings, this in itself was not a crime. Adams categorically denied that he had ever been a member of the Communist Party or that he had passed along secret information. He was acquitted on October 23rd, 1946.

Indeed, most of those who refused to co-operate fully with the Royal Commission secured acquittals, while those who co-operated, like McGill Chemistry Professor Raymond Boyer, were generally convicted. In the final analysis nothing in the treatment of the suspects from the suspension of their civil liberties through their cavalier handling before the Commission to the use of their testimony against themselves in criminal court would encourage anyone to co-operate with such a process. Even Mackenzie King was distressed at the process, writing in his diary:

It is an immense relief to have the Order in Council [allowing the Commission to detain suspects sine die] cancelled. I feel the Commissioners have thought more of themselves and doing a fine bit and of the report they are making than of the position in which they have placed the Government and our party. It will always be held against us and the Liberal party that we sanctioned anything that meant so much in the way of deprivation of liberty for a number of people. Moreover, as I saw at the start, it has raised an issue in the minds of the people even more important than that of the espionage and will probably result in several of the persons being freed altogether when they come before the Court, or given trifling sentences. It will be an interesting study in the power of public opinion and the preservation of freedom. ${ }^{24}$

After his acquittal Adams expressed the hope he could return to his job at the bank, but this was not to be. Shortly thereafter he left with his wife for an extended tour of Eastern Europe.

The usual conclusion of the general public to proceedings such as these is that the defendant is guilty 
but managed to get off in court tbrough some technicality or superior legal advice. Eric Adams has never publicly discussed the matter over the last fifty years. ${ }^{25}$ However, not everyone was certain of Adams' guilt. Humphrey, who knew many of the participants such as Fauteux and Robertson quite well, clearly had his doubts. When Eric and Josepha Adams returned to Canada in August, 1949, from their European visit, Humphrey was also a passenger on the R.M.S. Aquitania. He confided to his diary:

Last night I had a long talk with Eric and Jo Adams. The conversation gradually drifted to world politics. Perhaps I shouldn't have been surprised to discover that notwithstanding the experiences that Eric has gone through his ideas are apparently unchanged. There was the same incompatibility between us as there was, it must be over fifteen years ago, when in spite of this incompatibility we were close friends. Last night however there was a bitterness in his remarks which he nevertheless seemed at pains to bide. $\mathrm{He}$ has a good mind but it is rigid and, I suspect, totally without warmth. That he is still a marxist I have no doubt whatsoever. Was he really a Soviet spy? I doubt it; but [he] would probably be capable of it if intellectual consistency pushed him far enough. Of such stuff are fanatics made. ${ }^{26}$

\section{TROUBLES IN THE SECRETARIAT}

After the adoption of the Universal Declaration of Human Rights in 1948, right wing opposition to the United Nations did not slowly diminish. Indeed, the bigher profile that the Declaration gave the U.N. served to accentuate the hysteria. While the Truman State department was the principal target of Republican attacks, the U.N. served as the main example of State Department failings. The State Department was, in theory, responsible for security clearances of American nationals employed by the U.N., as well as providing accreditation for American representatives on various U.N. bodies. In fact, the only clearances given were for Assistant Secretary-General for Administrative and Financial Services, Byron Price, and U.N. General
Counsel, Abraham Feller. Secretary of State James Byrnes did not want to give the appearance of unduly influencing Trygve Lie in his choice of employees. ${ }^{27}$ In the late 1940s and early 1950s scores of these individuals were denounced in Congress and subject to investigations by Congressional committee and Grand Jury hearings for actual or potential disloyalty. The cases of a handful of these individuals are examined below. They share the common bond of being mentioned by Humphrey in his diaries or autobiography. A few he knew well, others he worked closely with, while the large majority were casual acquaintances with whom he came in contact during the exercise of his duties.

The disloyalty investigations went through three principal phases. The Tydings Commission, a Senate body controlled by the Democrats, was appointed to give a formal hearing to Joseph McCarthy's early allegations in 1950. A Federal Grand Jury was impanelled to investigate Communist activities in the New York area in 1952, focusing a great deal of attention on U.N. employees. Finally there were the ongoing investigations of various Congressional committees into un-American activities.

Many international servants, including Phyllis Chait, Humphrey's administrative assistant in the Division of Human Rights, were called to testify in these processes, and some pleaded the Fifth Amendment. For Humphrey, whose bitter opposition to McCarthyism and all it stood for is recorded elsewhere, ${ }^{28}$ this was the low point of his life in the Secretariat. Trygve Lie ultimately suspended, or dismissed in the case of temporary employees, any U.S. nationals who either refused to testify or testified unsatisfactorily before the Grand Jury hearings. He rationalized this on the grounds that pleading the Fifth Amendment was a breach of the staff regulations. ${ }^{29}$ Chait did testify before the Grand Jury and was able to retain her job.

Another employee of the Division on Human Rights, Ben Carruthers, lost his job apparently on moral, rather than ideological, grounds. Although there was no suspicion of left-wing leanings in his case, it was apparently felt that his lifestyle left him open to blackmail by those who had such leanings. ${ }^{30}$ The U.N. legal counsel, Abe Feller, deeply disturbed over the suspension of his colleagues' civil rights, committed 


\section{Humphrey and the Old Revolution}

suicide in November, 1952. Humphrey noted in his diary:

\begin{abstract}
Abe Feller committed suicide today. While nothing certain is yet known the tragedy apparently had its roots in a combination of over-work and implication in the current anti-red enquiries. His death is a tremendous loss to the Secretariat. I have always thought that he had one of the best minds in the High Command to which he most certainly belonged. And on the whole I had great respect for him although I was not always in agreement with him. ${ }^{31}$
\end{abstract}

An Appeals Board was put in place to hear the cases of officers who had been dismissed. Humphrey had some hope of saving Carruthers' job and appeared before the board. This hope was vain as his diary for February 4, 1953, noted:

The Bureau of Personnel will apparently stoop to any depth in order to win its cases against dismissed officers who have gone before Appeals Board. Thus, after hearing my evidence in the Carruthers case, Krac[z]kiewicz $z^{32}$ (apparently acting under instructions) reopened the case to say that when the S.G. decided to terminate Carruthers he had in mind budgetary factors and also his opinion that the work on which C. was engaged should be done in the D.P.I. This, of course, is an ex post facto rationalization and, what is worse, a damned lie: for K. was in my office only the other day discussing candidates for the Carruthers post. ${ }^{33}$

\section{THE AMERICAN DELEGATION}

American delegates to the U.N. were also subject to scrutiny as McCarthy attempted to disgrace the Truman State Department. His first target was Dorothy Kenyon (1888-1972), the American representative on the Commission on the Status of Women from 1947-1949. In the early days, Humphrey's relations with this body were not altogether smooth but he noted that he did make a friend of Kenyon. ${ }^{34}$ She was a lawyer and former judge, as well as a civil libertarian who espoused a number of causes. When the U.S. Senate established the Tydings Committee to hear McCarthy's charges against State Department employees in March, 1950 , the first person he accused was Kenyon whom he said was "affiliated with at least twenty-eight Communist-front organizations". He further stated that: "The Communist activities of Miss Kenyon were not only deep-rooted but extend back through the years" and

It is inconceivable that this woman could collaborate with a score of organizations dedicated to the overthrow of our form of government by force and violence, participate in their activities, lend her name to their nefarious purposes, and be ignorant of the whole sordid and un-American aspect of their work. ${ }^{39}$

Kenyon answered the charges quickly and emphatically. She called McCarthy an "unmitigated liar", challenged him to repeat his charges in a forum where congressional immunity did not apply, and demanded and received a hearing before the Tydings Committee. She expressed the hope that she could meet McCarthy face to face at the hearing, but McCarthy, perhaps wisely, found it "simply impossible for him to attend" that session. ${ }^{36}$ Kenyon's appearance resulted in her complete vindication and highlighted the totally insubstantial nature of many of McCarthy's allegations. Even McCarthy's ally on the Committee, Republican Senator Bourke Hickenlooper, agreed there was not the least evidence that Kenyon had ever been in any way subversive or disloyal. ${ }^{37}$ She was not even an employee of the State Department (although it had approved her appointment to the Commission), and so was never subject to the loyalty review process of which McCarthy was so critical. The final report of the Tydings Committee was extremely critical of McCarthy, almost to the point of using unacceptable language, and exonerated all of those about whom allegations were made.

McCarthy proved to be resilient. The Tydings Committee findings were dismissed in many quarters as a partisan attack on the junior Senator from Wisconsin. William F. Buckley's eloquent defense of McCarthy ${ }^{38}$ suggested that, while his methods were sometimes 


\section{Humphrey and the Old Revolution}

crude and his facts not always accurate, he had brought to the public attention genuine problems in the State Department security clearance system. With the change to a Republican administration in 1952, McCarthy was once more in the ascendant. One of Humphrey's State Department acquaintances, Esther Brunauer (19011959), ${ }^{39}$ whose responsibility was UNESCO liaison, had been named by McCarthy in the Tydings Committee hearings. She was alleged to belong to a number of Communist front organizations and there was a suggestion of guilt by association in that her husband, Stephen Brunauer, a Navy department scientist, had been a member of a Communist organization-the Young Workers' League-prior to 1927. McCarthy made the further preposterous claim that as an executive of the American Association of University Women, she steered that group towards pro-Communist consumer activities. Although she was cleared by the Tydings Committee, she was forced to undergo a series of loyalty and security checks over the next two years.

She could never refute the principal allegation of maintaining "close and habitual association " with her husband. ${ }^{40}$ In 1952, she was suspended, then fired, from the State Department as a security risk. ${ }^{41} \mathrm{Her}$ husband had earlier lost his job, resigning while under suspension prior to what seemed an inevitable dismissal. The same thing happened to a number of others who had been named before the Tydings Committee. Buckley uses these subsequent dismissals as proof of the accuracy of McCarthy's original allegations. Others would argue that the security clearance procedure became increasingly more rigorous to the point of extreme unfairness because of the climate of hysteria McCarthy had created.

\section{GUSTAVO DURÁN}

Humphrey enjoyed friendly relations and socialized with a number of his U.N. colleagues, including Gustavo Durán ${ }^{42}$ and his wife. He seems to have been unaware of Durán's colourful past, not even mentioning him in his autobiography of the U.N. years while the diary records only social meetings. Durán (1906-1969) was a musician and composer in Madrid when the Spanish Civil War broke out, a man of culture and something of a playboy. A reserve officer, he joined the army and was rapidly promoted, eventually becoming a Divisional Commander. $\mathrm{He}$ knew Hemingway, was mentioned by name in For Whom the Bell Tolls ${ }^{43}$ and was a hero to the those who supported the loyalist cause.

After Valencia collapsed and the war was lost, Durán sought asylum at the U.S. consulate but was refused. He was subsequently granted asylum by the British consul and escaped to England on HMS Galatea. He was invited by the military historian, B.H. Liddel Hart, to Dartington Hall, home of American Dorothy Straight Elmbirst, the owner of the New Republic and widow of American diplomat and businessman, Willard Straight. Her son, Michael Straight, observed about Durán that: "His taste was impeccable, his knowledge formidable, his talent overwhelming". ${ }^{44}$ Straight had married Belinda Crompton and her sister, Bonte, was visiting the Hall. Within three months Durán married Bonte Crompton. ${ }^{45}$ He moved to the U.S. in 1940 , becoming a naturalized citizen in two years instead of the usual seven. He held a number of jobs in New York and Washington, as well as attempting to help Hemingway, whom he had known in Paris in the 1920s as well as during the Spanish Civil War, on the draft of For Whom the Bell Tolls. ${ }^{46}$

In 1943 Durán moved to Havana where he helped run the Crook Factory, Hemingway's private antifascist counter-intelligence organization. The Crook Factory basically spied on Cuban Falangists and searched for U-boats during fishing trips on Hemingway's boat. He did not work well with Hemingway and soon began spending most of his time directing the intelligence activities of Spruille Braden, the American ambassador to Cuba. He moved back to the U.S. in 1945, working in the State Department as an expert on Latin America. In 1946 he joined the U.N. as a Social Affairs Officer in the Refugee Division. It was at approximately this time that rumours began circulating that he was a communist agent. Juan Perón, President of Argentina, mentioned this in a book and Durán was attacked in Arriba, a Madrid newspaper of the Falangist Party. ${ }^{47}$ The Spanish Intelligence Service provided the essence of the Arriba article to the U.S. Military Attaché in Madrid, Colonel Wendall Johnson. Johnson's report was forwarded to Washington "for general use by any U.S. Intelligence Agency". ${ }^{48}$ In 1947, Representative Alvin O'Konski started a vehement attack on Durán in Congress: 


\section{Humphrey and the Old Revolution}

I want to talk to you about how a notorious international Communist duped our State Department. It is the life story of Gustavo Duran... We had as an Assistant to the Assistant Secretary of State ... one of the most notorious international Communists the world ever knew...

I wish I had time to tell you the full import of the story in detail-his record step by step; his Communist connections; his connections with the International Communist Organization with its headquarters in Havana...; how he worked with the notorious $\mathrm{CIO}$ Communists in this country; how they started out on a campaign of smear against one of our southern neighbours, Argentina, and how that campaign of smear worked out... ${ }^{49}$

McCarthy himself renewed the attack during the Tydings Committee hearings in 1950.

Durán was well able to defend himself. He did not appear before the Tydings Committee, suggesting that to do so would be inconsistent with his role as an international servant under article 100 of the U.N. Charter. He did, however, provide a written response, demonstrating that the allegations were based on old Fascist propaganda and the ill-will of Juan Perón. He provided documentation to show that the State Department had investigated all these allegations in 1945. At that time he had testified before the loyalty board of the U.S. Civil Service Commission, explaining his Civil War relationship with the Communists as follows:

I must add in this connection, even at the risk of being misunderstood, that during the first years of the Spanish Civil War all I saw of Communist behaviour was the performance on the front line of those individual Communists who were among the military units that I commanded, and that from the point of view of courage and discipline their performance was in accordance with recognized military standards. As a result (a natural result in times of war), my attitude towards them, like the attitude of practically all the Republican military leaders at the time, was friendly. It became increasingly hostile as I gradually learned of the ruthless methods and duplicity of the Communists, of their attempt at complete control of any situation in which they happened to participate, of the fact that their primary allegiance went not to the Government they professed to serve but to their party, and finally that the instructions that that party received were not founded in any idealism but in very specific interests which were far from identical with those of the Spanish people. ${ }^{50}$

The Tydings Committee concluded that McCarthy had perpetrated "a fraud and a hoax" and "perhaps the most nefarious campaign of half-truths and untruths in the history of this Republic". Durán was exonerated with all the others McCarthy had named. As with the others, the persecution continued after the change in administration. He was obliged to appear before the Committee on Un-American Activities in 1953. Unlike those who were still employed by the State Department, he did not lose his job.

Despite the foregoing, during his time in Spain at least, Durán was certainly a Communist. ${ }^{\text {S1 }}$ When Indalecio Prieto, the Republican Minister of Defense, created SIM, the military intelligence service, in August, 1938, he appointed Durán to take charge of the Madrid zone. The appointment was urged on him by Alexander Orlov, the chief NKVD agent in Spain. Prieto told the Socialist national committee that "It was not concealed from me that he was a Communist. I knew that he was, but I nevertheless appointed him". When Prieto dismissed Durán, apparently because he was appointing too many Communists to SIM, Orlov threatened to break off relations with Prieto unless be was reinstated. Durán was not reinstated and the incident caused a major split between the Socialists and the Communists. The Spanish Communist Party, in its official history of the Civil War published in Moscow in 1977, clearly identifies Durán as a member of the Party. Prieto wrote to Durán that he had never accused him of being "an agent of the Russian police nor a member of the Comintern". ${ }^{52}$ There appears to be no evidence that he continued to be a communist sympathizer after the Civil War and it is understandable 


\section{Humphrey and the Old Revolution}

that he should deny that he was ever one in the U.S. in the 1950s. He went on to have a distinguished U.N. career in New York, Chile, the Congo and Greece, where he died in 1969. He is revered in the Greek village where he is buried not for his more newsworthy activities but rather as the man who brought running water to the community.

\section{LEO MALANIA}

Attacks by the American right on non-American international servants were quite common, although less career-threatening than to their American colleagues. Another colleague of Humphrey's was Leo Malania, a Russian-born naturalized Canadian. He began his U.N. career as an Executive Officer in the Department of Economic Affairs and, by 1949, was Chief Administrative Officer of the U.N. Palestine Commission. An anonymous witness, testifying before the Senate Judiciary Committee, stated Malania conspired with Secretary-General Trygve Lie to enact a Communist inspired reign of terror in the Secretariat. This was to be achieved by hiring Communists into key posts. Malania "has very close ties with the Soviet delegates" and was responsible for most of the biring in the Economic Department. Lie was in Europe and Assistant Secretary-General Byron Price replied to the accusation:

This is the nuttiest story I have heard yet.

I am in a position to know that the charges relating to the administrative policies of Secretary-General Trygve Lie and the personnel policies of the United Nations are fantastically untrue.

I am sure no fair-minded person will attach significance to the statement of a mysterious so-called "official" who attempts wild character assassination of his colleagues, but refuses to gives his name. ${ }^{53}$

Price's denial is especially convincing since he apparently approved of and cooperated fully with the un-American activity investigations, although it is possible that he was following Lie's instructions. Humphrey was disgusted with the ongoing investigations and the Secretary-General's response. He wrote in his diary:

The Americans have begun to finger print their compatriots in the Secretariat; and Byron Price proudly presented himself to be the first victim. The thing that makes this crowning indignity most objectionable is that it is being done with Lie's approval and by U.N. officials and on U.N. premises. ${ }^{54}$

Basically Trygve Lie caved in under the pressure and his attempt at justification for his actions seems unconvincing. ${ }^{55}$ In general, Americans accused in the "witch hunt" lost their jobs, although most won financial compensation on appeal. Non-Americans were left, after the investigation lost its momentum, to pursue their careers in relative peace. Malania subsequently became Chief Editor in the U.N. Publications Division. He retired in 1965, taking the post of Minister at St. David's Episcopal Church in Queens, N.Y.

\section{LOUIS DOLIVET}

Malania's anonymous accusor named another Humphrey acquaintance as being involved in Trygve Lie's "reign of terror". Louis Dolivet ${ }^{56}$ was stated to have used his position as Editor of United Nations World (a commercial publication unconnected with the U.N.) to act as liaison between the Secretariat and the Russian delegation.

Dolivet was the Director of the Rassemblement Universel pour la Paix in Paris in the 1930s. He joined the French Air Force during the war, escaping to the U.S. when his unit surrendered. In 1941 he met and subsequently married American actress, Beatrice Straight, daughter of Dorothy Straight Elmhirst. A passionate believer in the U.N. and its role in achieving world peace, he wrote the first handbook ${ }^{57}$ on the organization and dedicated it To those who live as citizens of one world and who act as members of one humanity. He edited Free World and later, with the financial assistance of his mother-in-law and other wealthy investors including Nelson Rockefeller and Max Ascoli, the United Nations World. Dolivet's best friend was Humphrey's immediate superior and good friend, Assistant Secretary-General Henri Laugier. It 
was inevitable that Humphrey and Dolivet would see a lot of each other in New York and in Europe. Humphrey's diaries give an insight into the relationship:

Antibes, Sun. 23 Sept. [1951]

Great talk today about the United Nations with Laugier and also Louis Dolivet who is another house guest here...

In the evening after dinner we, Jeanne and I, went for a long walk with Dolivet. Extremely well informed and intelligent but his conclusions sometimes lack weight. Is his judgement sound? Is he a wishful thinker?

Tue. 25 Sept.

We drove to Vallauris this morning where we met Picasso. Marie ${ }^{58}$ went in first after which P's young wife, Françoise, invited Laugier to come in, indicating that Dolivet, Jeanne and I might possibly come in later. We idled away our time stealing and eating P's grapes which were very good. Finally $P$. came down the steps and greeted us most cordially. I was impressed by the vitality of this man of 71 years. His black eyes shine with intelligence and the vigour of a twenty year old. Even if one did not know he is a great painter one would nevertheless put him down as a remarkable man.

Dolivet's fortunes began to turn in 1946, when all his investors except the Straight family withdrew, and the United Nations World began to experience some economic difficulty. His wife, who had left the theatre to have a son, Willard, now wished to return to acting. This eventually led to a split with Dolivet, who refused to consent to a divorce. The family was told by its lawyer that an annulment could be gained if it could be proved that Dolivet had concealed important truths about himself from his wife. Dolivet had told his wife nothing about his childhood and life in Europe, saying only that it was too painful to talk about. A former Naval Intelligence officer and international investigator, Ladislas Farago, was hired to enquire into Dolivet's past.
In April, 1947, the Washington Evening Star published an article by Constance Brown which stated Dolivet was not French, but a Rumanian named Ludovico Brecher, an important agent of the Communist International. The well-connected Farago was able to gain access to the intelligence files of four countries, as well as the U.S. He brought back a great deal of material "all of which was defamatory and most of which was unverifiable". ${ }^{59}$ After examining this documentation Farago concluded Dolivet had been born in Galicia and his parents had moved to Rumania. He had gone to France, via Switzerland, on his own as a teenager. The family checked the marriage certificate to see how Dolivet had signed it, thinking it might support their case if he had used a false name. Dolivet had added "L.B." beside his signature.

Dolivet eventually agreed to a divorce and joint custody agreement. The divorce was granted in May, 1949, and Dolivet returned to France, since he had no further financial backing, intending to return shortly. Dolivet's trips to the U.S. had been on a visitor's visa and, from 1947, with U.N. accreditation, although he had applied for U.S. citizenship in 1946. In May, 1950, Representative Jenison of Illinois, a member of the House Un-American Activities Committee addressed Congress on the question of Dolivet's visa and request for citizenship..$^{60} \mathrm{He}$ added to the previous allegations by presenting "facts" about Dolivet's activities in the $1930 \mathrm{~s}$ "documented by sources of unquestioned integrity". Jenison's principal source was a translation of a French magazine article by one of Dolivet's opponents, identified as A. Rossi, "a man whose integrity has been vouched for". As a result of the debate in Congress, the State Department bowed to the pressure and Dolivet's visa was revoked.

Living in France, Dolivet became Secretary-General of Democratie Combattante, an international organization devoted to the promotion of peace through the United Nations. The organization had been formed by Socialist leader and Nobel laureate Leon Jouhaux as a non-Communist workers' party after he broke with the Communists. Laugier had helped him in the establishment of the organization. In 1952, Dolivet's son Willard was drowned. He applied for an emergency visa which, after appeal to Secretary of State Dean Acheson, was denied. The reasons given were that Dolivet had been a communist since 1933 and that 


\section{Humphrey and the Old Revolution}

Democratie Combattante was a Communist front. Laugier represented him at the funeral.

Humphrey remained friendly with Dolivet and continued to see him in his new role. He was aware, at least partially, of the nature of the allegations about Dolivet, but clearly did not give them much credence. On December 13, 1951, he noted in his diary:

King Gordon is disturbed about plans to have Dolivet do some work for us. But what can I do? Apart from any personal desire I might have to help this man, the pressure to do something for him comes from sources that are most influential - the S.G. himself, Cassin, Laugier ... Moreover Dolivet has brains and I don't believe the scandal about him.

Dolivet had always been one of the U.N.'s great promoters and so, in his adversity, the U.N. continued to employ him in a consulting capacity. Humphrey had frequently resisted pressure from above to hire people he considered unsuitable, but it is clear that his sympathy was with Dolivet in this case. Dolivet eventually remarried and became a successful entrepreneur. When the London Sunday Times decided to do an exposé of him in 1981, rehashing the old stories based on newly released FBI files, Dolivet was able to stop them with a court injunction.

\section{MICHAEL STRAIGHT}

Humphrey was also acquainted with Michael Straight, ${ }^{61}$ related by marriage to both Durán and Dolivet. Straight was a peace activist who used his role as editor of the New Republic to promote these ideas. He occasionally met Humphrey for lunch to keep up with U.N. activity in the area of human rights, and wrote a number of articles on this topic. Humphrey's relationship seemed purely professional and there is no evidence in the diaries that he even knew of Straight's connection with Durán and Dolivet. Straight is not even mentioned in Humphrey's autobiography of the U.N. years. Yet Straight kept the deepest and darkest secret of all. Whatever the truth may be about Durán, Dolivet and Adams, Straight had certainly been clandestinely recruited as a Soviet agent.
Straight was born on Long Island in 1916 to a wellconnected and, on his mother's side, wealthy family. His father died two years later of disease in Europe after the First World War. In 1925 his mother married an Englishman, Leonard Elmhirst, and subsequently established Dartington Hall in Devon as a utopian community. Straight attended school at Dartington and then went to Cambridge University in 1934. As an undergraduate, like so many others at the time, he had Marxist leanings and was committed to world peace through Communism. He visited Russia in 1935 where he met Anthony Blunt, a recent graduate of Cambridge. He was admitted to the Apostles, a leftist secret society, where he met Guy Burgess and became reacquainted with Blunt. Blunt recruited him as an agent of the Communist International while he was emotionally disturbed after his friend, John Cornford, was killed in the Spanish Civil War.

It had always been Straight's intention to remain in England. However, in 1937, Blunt informed him that it had been decided he should return to the U.S. and wait to be contacted. Straight made some half-hearted attempts to escape from his commitment, but ultimately accepted this directive after graduating from Cambridge. He worked for the State Department, securing a job on the recommendation of his mother's friend, Eleanor Roosevelt. He later worked for the Department of the Interior before moving in 1940 to the New Republic, which had been founded by his father and was still owned by his mother.

Straight was approached several times during his government service by "Michael Green", a Soviet agent who was his controller. Straight maintains that he never passed on secret information (or even possessed any) and that all he gave was his opinion on various matters. He told Green he would help him no further when he joined the USAF in 1942, and never saw him again. He continued to see Guy Burgess, then with the Foreign Office, from time to time but refused to co-operate with him. After one such meeting, when Straight became convinced that Burgess was also a Soviet agent, he confessed his past to his wife, Belinda Crompton, whom he had married in 1939. Burgess and Donald Maclean subsequently defected to the Soviet Union in 1951, just before action was to be taken against Maclean. Kim Philby, also part of the espionage network, defected in 1963 after confessing that he had helped warn Maclean. 


\section{Humphrey and the Old Revolution}

A few months after Philby's defection and Burgess's death in 1963, Straight was offered the chairmanship of President Kennedy's Advisory Council on the Arts. As with all such nominations, there would be a routine FBI investigation of his past. Straight feared that his past might not stand up to rigorous scrutiny, and decided to "come in from the cold". He went to Presidential Advisor Arthur Schlesinger and told him the story. At Straight's request, Schlesinger called the AttorneyGeneral, Robert Kennedy, who arranged for Straight to meet with William Sullivan, Deputy Director of the FBI. The information that Straight gave to Sullivan about Blunt, as well as his suspicions about Leo Long, another Cambridge undergraduate, was given to MI5 in January, 1964. Faced with Straight's evidence both Blunt, with the promise of immunity, and Long confessed to their wartime espionage role. The British government decided to keep the whole matter quiet, believing that immunity also implied anonymity.

In the long term, however, there is little anonymity from the British press. Broader and broader hints were dropped that there were other moles in British intelligence. Eventually, in 1979, Prime Minister Thatcher acknowledged in Parliament that Blunt had recruited for Soviet intelligence while he was at Cambridge and "passed information regularly to the Russians while he was a member of the Secret Service between 1940 and $1945^{\prime \prime} .{ }^{62}$ Blunt, by then Sir Anthony Blunt, Surveyor of the Queen's pictures, was stripped of his honours. In 1981, Straight was interviewed by the Sunday Times and gave the name of Leo Long. After the publication of that article, Thatcher answered another question in the House as follows:

Early in 1964, Leonard Henry Long was
named to the Security Service by Mr.
Michael Whitney Straight, the United States
citizen who identified Anthony Blunt, as
someone else Mr. Blunt might have
attempted to recruit as an agent for the
Russian Intelligence Service. When Mr.
Blunt made his confession in April 1964, he
admitted to having recruited Mr. Long
before the war and controlled him during
it. ${ }^{63}$

Later Straight, who felt be was wrongly identified in the newspapers as an American who spied for the
Russians, gave his side of the story in an autobiography.

\section{THE IMPACT OF HUMPHREY'S ASSOCIATIONS}

At first glance Humphrey's circle of acquaintances seems to have an unusually high proportion of admitted or alleged Soviet agents, but in retrospect this is not surprising for at least two reasons. First, the McCarthyite allegations were so widespread and allinclusive that they were made against virtually anyone who was left of centre or who espoused liberal causes. Second, Humphrey felt most at home in left-wing intellectual circles, where world peace and just societies were matters of the greatest concern. The NKVD did much of its recruitment in such circles. Had Humphrey been ten years younger, he might himself been the object of such recruitment during his university years.

While Humphrey's relationship with Adams probably escaped official scrutiny, it is virtually inconceivable that the same would be true of his relationships with people such as Durán and Dolivet. Since they were the object of investigation by the FBI and other intelligence agencies and since Humphrey himself held a high-level diplomatic post, dossiers would certainly have been created on him. While these dossiers probably still exist, and access could be gained to them under freedom of information legislation, nothing was made public about Humphrey's relationships with suspected individuals during the crucial first few years of bis twenty-year tenure as Director of the Division on Human Rights. It is difficult to imagine how Humphrey could have remained in his position and been effective if he had been the subject of public attacks by the American right. An early resignation by Humphrey would have clearly affected the directions taken by the U.N. human rights programme, given SecretaryGeneral Dag Hammarskjöld's desire to close it down for all practical purposes, ${ }^{64}$ and might have retarded the slow acceptance of the Declaration.

The fact that Humphrey knew these individuals who fell under suspicion seems to have had no negative affect on his career, probably because, with the exception of Dolivet and Durán, his acquaintance with them was so very slight. ${ }^{65}$ Humphrey's career was probably more impeded by his criticisms of Canadian 
activities within the United Nations. He was shocked by the Canadian abstention on the adoption of the Universal Declaration in the Third Committee on December 8, 1948. Two days later, when Canada voted for the adoption in the General Assembly, he categorized Pearson's speech as "one of the worst contributions" and a "niggardly acceptance". ${ }^{66}$ Thereafter the diaries abound with criticisms of the positions taken by Canada, some of which he conveyed to officials, such as his discussions with Paul Martin about Canada's refusal to repatriate evacuated Polish children and treasure. ${ }^{67}$ On another occasion he confided to his diary:

Thur. 16 November [1950, Great Neck]

The Committee adopted a very good resolution today on Human Rights Day. I had a good deal to do with the drafting and am also partly responsible for the initiative.

I was disgusted with the Canadian delegation which voted with the Soviet bloc in favour of a suggestion which would have combined the day with U.N. Day on 24 October. Nothing could be less imaginative than the Canadian record in the U.N. in relation to human rights. One would think that the delegation would have learned a lesson in Paris.

Viewed objectively, Humphrey's criticisms of Canada's record seemed a trifle unfair when that record is compared to those of some other countries. He appeared to use a double standard. When other nations took actions of which he personally disapproved-and they frequently did - he accepted this fact as only to be expected. When Canada did the same, he became far more critical because his expectations of his beloved homeland were far bigher. An international servant is expected to remain neutral in such circumstances but the diaries make it clear that Humphrey let his feelings show from time to time.

It is speculative to judge what affect this may have had on Humphrey's career. Nevertheless, by 1950 the Human Rights Division was riding the crest of the wave created by the success of its work on the Universal Declaration and other considerable activities. There was talk of elevating the Division to the rank of Department with an Assistant Secretary-General in charge.
Humphrey hoped that Henri Laugier would be that Assistant Secretary-General, but Laugier had by this time determined to leave the United Nations. Laugier endorsed the principle of a Human Rights Department, but felt that Humphrey should be the A.S.G. The diaries show, however, that Humphrey knew the cost of his actions:

\begin{abstract}
Wed. 1 March [1950, Great Neck]
.....

Had a long talk with Laugier this afternoon about his successor. He wants very much a Department of Human Rights and says that I should be its A.S.G. He has even made quite a campaign for this amongst delegations. But I have no illusions. I could only become A.S.G. if I had the energetic and enthusiastic support of Ottawa-and that I never expect to have.
\end{abstract}

In the event, this opportunity was lost and the Division slowly lost influence when the Departments of Social Affairs and Economic Affairs were merged and the programme fell out of favour with SecretaryGeneral Hammarskjöld. It was not until 1982, long after Humphrey's retirement, that the Division was made the Centre for Human Rights and its Head reclassified as an Assistant Secretary-General.

\section{CONCLUSIONS}

The Universal Declaration of Human Rights has evolved from a resolution of the General Assembly, which imparted no binding obligation to any state, to the point where it is, in the view of many authorities, part of the customary law of nations. While the two covenants on civil and political and on social and economic rights do impart binding obligation, neither has been signed by a majority of member states. Conversely, articles from the Declaration are frequently cited in litigation and petitions, and are accepted as precedents by international tribunals. It has an impressive moral authority. Indeed, after almost half a century, the world is slowly catching up with the farsighted vision of its drafters. Social security has been accepted in the West, while civil and political rights are now enjoyed in the former Soviet empire and South Africa. 


\section{Humphrey and the Old Revolution}

One is forced to wonder whether the Declaration could have achieved this stature if, in its early days, Humphrey, who wrote the first draft, had been hounded into resignation because of leftist connections. Would Holman's view - that it was an attempt to establish State socialism if not Communism-have gained greater credence resulting in a rejection of the Declaration in the West? Such questions can never be answered. The Declaration is considered by many to represent the high point of what the U.N. has achieved. Solzhenitsyn, in his Nobel acceptance speech, called it the "best document" produced by the U.N. in all its history. ${ }^{68}$ Holman's view, on the other hand, has been relegated to the status of an illustration of a dark period of American history. Rights triumphed over the right, and this is as it should be.

\section{Notes}

1. Muhammad Zafrulla Khan (1893-1985), Pakistan's Minister of Foreign Affairs and leader of its delegation to the U.N., was able to convince other Islamic nations not to abstain with an eloquent defence of the Declaration in the plenary.

2. American Academy of Political and Social Science. Annals, v. 255 (1948), 21.

3. Louis Dolivet was a friend of Henri Laugier, Assistant Secretary-General for Social Affairs and Humphrey's immediate superior. He will be dealt with at length later in this article.

4. John P. Humphrey, On the Edge of Greatness: the Diaries of John Humphrey, First Director of the United Nations Division of Human Rights. Ed. by A.J. Hobbins. (Montreal: McGill University Libraries, 1994). Vol. I, 1948-1949, 45. References are made to this edition for the diaries of 1948 and 1949. For 1950-1966 the citations are to the manuscripts, held in McGill University Archives.

5. American Bar Association. Joumal, v. 34 (October, 1948), 881-885.

6. Humphrey met Frances Carlisle (1917- ) by chance on the S.S. Excambion in December, 1948. During her service with External Affairs she met and married her colleague, Herbert Owen Moran, in 1952. Moran served as Canadian Ambassador or High Commissioner to a number of countries before he retired in 1972 .

7. Humphrey, On the Edge of Greatness, 99.

8. Humphrey, On the Edge of Greamess, 105

9. Barry Goldwater, Why not Victory? (New York: McGrawHill, 1962), 102.

10. For an excellent history of the League see Michiel Horn, The League for Social Reconstruction: Intellectual Origins of the Democratic Left in Canada, $1930-1942$ (Toronto: University of Toronto Press, 1980).

11. Frank R. Scott (1899-1983), Canadian constitutional lawyer and poet, was Humphrey's colleague on the McGill Faculty of Law.

12. David Lewis (1901-1981) later became an M.P. and leader of the League's descendant, the New Democratic Party.

13. Frank Underhill (1889-1971) was a noted historian and educator. The University of Toronto attempted unsuccessfully to dismiss him for his political views in the 1950s.

14. Eugene Forsey (1904-1991) was at this time a lecturer in the McGill Department of Economics and Political Science. When he failed to obtain tenure, he became Director of Research for the Canadian Labour Congress.

15. (John) King Gordon (b. 1901) was a United Church Minister and educator. He worked for Humphrey in the Division of Human Rights from 1949-1954.

16. Humphrey, Diary, September 20, 1951.

17. Humphrey, On the Edge of Greatness, 39.

18. Arthur Wentworth Roebuck (b. 1878) was a Canadian lawyer, newspaperman and politician, who was summoned to Senate in 1945.

19. Humphrey, Diary, April 20, 1950.

20. The facts concerning Adams and Igor Gouzenko are mainly taken from J.W. Pickersgill and D.F. Foster, The Mackenzie King Record (Toronto: University of Toronto Press, 1970) Vol. IIl, Robert Bothwell and J.L. Granatstein, The Gouzenko Transcripts (Ottawa: Deneau Publishers, 1982) and the Royal Commission to investigate the Facts Relating to and the Circumstances Surrounding the Communication, by Public Officials and Other Persons in Positions of Trust of Secret and Confidential Information to Agents of a Foreign Power, Report (Ottawa: King's Printer, 1946).

21. Pickersgill, 9.

22. Royal Commission, Report, 226. In this regard the transcript of Adams' cross-examination reads in part:

Q. Would you care to explain that telegram?

A. Sure. Ever since I have started travelling, which is a good many years ago, my wife and I have had an arrangement whereby if she is ever in trouble and wants to see me come home, and does not want to talk about the whole thing in a telegram, she simply sends me a telegram that Helen's baby is sick.

The Commissioners added: "Needless to say we do not believe his explanation".

23. Ibid. The Soviet Military Attaché, Colonel Nicolai Zabotin, ran the spy ring.

24. Pickersgill, 157-158.

25. When I spoke to Adams on a completely unrelated matter he said he never talked about the issue because all it did was stir up a lot of unwanted publicity.

26. Humphrey, On the edge of Greatness, 209.

27. Trygve Lie, In the Cause of Peace (N.Y.: MacMillan, 1954), 387. 


\section{Humphrey and the Old Revolution}

28. A.J. Hobbins "Human Rights inside the United Nations" Fontanus v. 4 (1991), 156-163.

29. Lie, 395.

30. Hobbins, 160-162.

31. Ibid., 160.

32. Karol Kraczkiewicz was a Personnel Officer in the Office of Personnel, Department of Administrative and Financial Services.

33. Hobbins, 162.

34. John P. Humphrey, Human Rights and the United Nations: a Great Adventure (Dobbs Ferry, N.Y.: Transnational Publishers, 1984), 30.

35. Fred Cook, The Nightmare Decade: the Life and Times of Senator Joe McCarthy (New York: Random House, 1971), 188-189.

36. Ibid., 190.

37. Ibid., 194.

38. William F. Buckley and L. Brent Bozell, McCarthy and his Enemies: the Record and its meaning (Chicago: Regnery, 1954).

39. For details on the Brunauer case, see also Richard M. Fried, Nightmare in Red: the McCarthy Era in Perspective (New York: Oxford University Press) and Notable American Women: the Modern Period (Cambridge, Mass.: Belknap Press, 1980). Humphrey met Brunauer in connection with his attendance at the second Conference of the U.S. National Commission for UNESCO in Cleveland.

40. Fried, 26.

41. For the remainder of her career, Brunauer worked briefly for the Library of Congress and then as an editor for the Rand McNally and Follet companies.

42. The majority of facts concerning Durán are taken from Burnett Bolloten, The Spanish Civil War: Revolution and Counterrevolution, (Chapel Hill: University of North Carolina Press, 1990), 547-549, Jeffrey Meyers, Hemingway: a Biography (New York: Harper and Row, 1985), 369-378, Robert Griffith, The Politics of fear: Joseph R. McCarthy and the Senate, (Lexington: University of llinois Press, 1970), 39, 71, Richard M. Fried, Men Against McCarthy, (New York: Columbia University press, 1976), 44 ff., and Michael Straight, After Long Silence, (New York: Norton, 1983), 265272. Humphrey first met Durán and his wife at the same UNESCO conference where he met Brunauer.

43. Ernest Hemingway, For Whom the Bell Tolls (New York: Scribner, 1940), 335.

"Just remember Durán, who never had any military training and who was a composer and lad about town before the movement and is now a damned good general commanding a brigade. It was all as simple and easy to learn and understand to Durán as chess to a child chess prodigy." 44. Straight, 268.

45. Meyers, 371. Straight, 268, has a somewhat different version, saying Durán went to Dartington at the invitation of a mutual friend, Michael Young, and that Straight's mother acted as matchmaker.
46. It was too late to incorporate Durán's suggested changes into the galleys.

47. Griffith, 71. The Arriba article appeared in the issue for April 9, 1946.

48. Buckley, 142.

49. Congressional Record, 80th Congress, 1 st Session, March 13, 1947, 2046.

50. Bolloten, 548-549.

51. Bolloten's carefully documented study leaves no possible doubt about this.

52. Buckley, 144.

53. New York Times, July 24, 1949, 10.

54. Humphrey, Diary, January 29, 1953.

55. For Lie's side of the story see his In the Cause of Peace (New York: Macmillan, 1954). James Barros provides a telling analysis of Lie's role in Trygve Lie and the Cold War (Dekalb, Ill.: Northern Illinois University Press, 1989). Humphrey's view is found in Hobbins, 156-163.

56. The facts concerning Dolivet are largely based on Straight, After Long Silence, 252-258, the Humphrey Diaries, newspaper articles and speeches.

57. Louis Dolivet, The United Nations: a Handbook on the New World Organization (London: Phoenix House, 1946). 58. Marie Cuttoli, Laugier's companion.

59. Straight, 255.

60. Congressional Record, 81st Congress, 2nd Session, May $25,1950,7764-7767$.

61. The facts about Michael Straight are taken from his autobiography (see above), Barrie Penrose and Simon Freeman, Conspiracy of Silence: the Secret Life of Anthony Blunt (London: Grafton, 1986), and Andrew Sinclair The Red and the Blue: Cambridge, Treason and Intelligence (Boston: Little, Brown, 1986).

62. Times (London) November 16, 1979, 2.

63. Times (London) November 10, 1981, 8 .

64. Hobbins, 163-165. Humphrey considers his greatest contribution to the human rights programme had nothing to do with the Declaration, but rather keeping the programme going at all in the face of Hammarskjöld's hostility.

65. So slight that Humphrey, reading an earlier draft of this paper two weeks before his death, could not recall the majority of people mentioned at all. Indeed, he felt that their histories had no relevance to a discussion of himself whatsoever. Certainly neither they, nor their views, influenced him in any way, and he questioned the point of the latter part of the article and the wisdom of publishing it. $\mathrm{Had}$ he lived, the article would not have been submitted for publication until we could have resolved this issue as we had always done before. I hope that the final draft would have satisfied his concerns.

66. Humphrey, On the Edge of Greatness, 90.

67. Ibid., 238.

68. Alexander Solzhenitsyn One Word of truth... (London: Bodley Head, 1972), 21. 